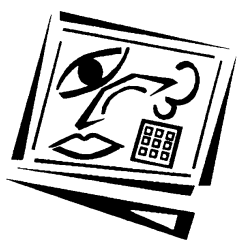

\title{
Effective practice with e-portfolios: How can the UK experience inform implementation?
}

\author{
Gordon Joyes \\ University of Nottingham \\ Lisa Gray \\ Joint Information Systems Committee, UK \\ Elizabeth Hartnell-Young \\ University of Nottingham
}

An Outstanding Paper Award recipient, ascilite Auckland 2009 Conference

\begin{abstract}
This paper introduces the background to the JISC work within the e-portfolio domain in the UK and presents an overview of past and current activities and the drivers for these developments. This is followed by a review of JISC's approach to drawing out the learning and implications for e-portfolio practice from this extensive collection of work and its dissemination. The analysis of twenty one recently funded projects involving the use of e-portfolios in the UK is introduced. The findings suggest that eportfolio implementation is particularly complex in part due to the number of stakeholders involved, the contexts in which e-portfolios can be applied and the number of purposes they can have. This research suggests that there are threshold concepts related to e-portfolio implementation and that developing an understanding of effective practice is not straightforward. However a means of supporting this understanding is suggested.
\end{abstract}

\section{Introduction}

The JISC (Joint Information Systems Committee) is a UK-based organisation which enables colleges and universities throughout the UK to benefit from the use of digital technologies. JISC invests in research and development in the innovative and appropriate use of emerging and existing technologies, and shares expertise through a range of specialised services providing information, advice and training, a trusted technical infrastructure and access to a wealth of digital resources.

Within the JISC e-Learning program (JISC, 2009a), funded projects and activities are working towards a vision where UK further and higher education are enabled to create a better learning environment for all learners, wherever and however they study. This program incorporates five main areas of activity - e-assessment, e-portfolios, learning resources and activities, e-administration for learning and teaching, and technology supported learning environments. In the area of e-portfolios, JISC aims to explore and develop effective practice in the use of e-portfolio systems and tools through the codevelopment of standards and piloting of e-portfolio related technologies and standards. They work in partnership with other sectors and bodies to develop and provide guidance to institutions on effective practice in the use of e-portfolios to support lifelong and lifewide learning. 
JISC work in the e-portfolio domain, the drivers for this and the approach used to disseminate effective practice are discussed below. The later part of the paper discusses research into the outcomes of projects implementing e-portfolios and the approach used to enable projects to capture evidence of benefits, user experiences and issues. The evidence captured reveals tangible benefits for users but the lessons emerging from projects have also revealed a number of common and often unhelpful preconceptions about e-portfolios by those introducing them. We then suggest an approach to supporting the implementation of e-portfolios that explores the notion of threshold concepts and the complexity of the domain.

\section{Background and context}

\section{Why is JISC exploring e-portfolios?}

The increasing interest in the potential for e-learning tools and technologies to support more learner centred and personalised forms of learning has been prompted in part in the UK by national strategies for e-learning and initiatives in favour of lifelong and personalised learning (see JISC, 2009k for some examples of these). In particular the higher education expectation for a Personal Developing Planning (PDP) policy to be in place by 2005/2006 (QAA, 2001) has been a key driver for institutional e-portfolio initiatives over the last few years. However this has not just been driven by top down initiatives. Within higher education institutions in the UK the importance of retaining students, widening participation, and increasingly, reflective learning (particularly in professional disciplines such as medicine) have also contributed to widening interest in e-portfolio tools and technologies.

Before learners enter higher education, within schools and 14-19 sectors, there has been an increasing focus on a national curriculum that values skills. A new qualification, the Diploma has emerged, with the development of personal, learning and thinking skills (PLTS) at its core. E-portfolio technologies provide ways in which these skills can be evidenced. But perhaps the most important reason for considering the potential of eportfolios to support learning and teaching is the emerging evidence from practitioners and learners of the value of developing e-portfolios, not only to support more profound forms of learning, adding value to personalised and reflective models of learning, but also facilitating the transition between institutions and stages of education, supporting application to education and employment, staff appraisal and applications for professional accreditation, and supporting learners based in the workplace.

\section{What are e-portfolios?}

There have been various definitions of e-portfolios, but JISC is working to an emerging consensus that the term encompasses both product and process.

An e-portfolio is the product, created by the learner, a collection of digital artefacts articulating experiences, achievements and learning. Behind any product, or presentation, lie rich and complex processes of planning, synthesising, sharing, discussing, reflecting, giving, receiving and responding to feedback. These processes referred to here as 'e-portfolio-based learning' - are the focus of increasing attention, since the process of learning can be as important as the end product.' (JISC, 2008b) 
Learners may create multiple e-portfolio presentations, for a range of purposes, for different audiences, at different times. For example, for presenting evidence of skills and achievements to an employer, or presenting reflections on a work placement as part of a course of learning. Tools to support the processes mentioned above may be as part of a single e-portfolio system, or selected independently by learners as appropriate. Useful definitions of e-portfolios also tend to include the concepts of learners drawing from both informal and formal activities to create their e-portfolios, which are personally managed and owned by the learner, and where items can be selectively shared with other parties such as peers, teachers, assessors or employers (Beetham, 2005).

\section{JISC and e-portfolios}

The JISC e-Learning Programme (JISC 2009a) has funded a range of activities in the eportfolio domain starting as far back as 2002 with the Managed Learning Environments (MLES) for Lifelong Learning program of twelve funded projects, during which the eportfolio concept emerged (JISC, 2009b). One of the key outputs from this program was a briefing paper providing an overview of e-portfolios and the implications for institutions (JISC, 2006). Legal guidance was also developed as part of the Legal and Records Management study, exploring the legal implications of these new technologies: in particular, the implications of learner ownership of data for institutions (JISC, 2009c).

In 2004, the Distributed e-Learning Programme took forward these concepts in the funding of twenty-one two-year projects exploring the use of technology to support lifelong learning (JISC, 2009d). The stories emerging from these projects were published in a briefing paper in April 2008 (JISC, 2008a), which brought to the fore effective practice surrounding the use of e-portfolios to support widening participation and progression. This practice was taken forward in the funding in 2006-2009 of projects exploring the use of technology in the contexts of higher education level courses delivered in further education settings (JISC, 2009e), lifelong learning (JISC, 2009f, 2009g), enhancing the administrative processes faced by teaching staff (JISC, 2009h), admissions (JISC, 2009i) and ensuring interoperability between e-portfolio systems (JISC, 2009j).

An overview paper (JISC, 2007) provides further detail around these projects and the contexts within which they were working. Broadly, these projects explored e-portfolio use to support the following main purposes:

- Application: providing a selection of material for application for admission to study or job, appraisal, induction or assessment

- Transition: through presenting a richer picture of learners' achievements on application, and in better preparing for the transition to a new environment

- Learning, teaching and assessment: supporting the assessment of learning, evidencing competencies or standards for summative assessment; and supporting assessment for learning by encouraging learners to present their experiences, achievements and reflections, share with peers, tutors and employers, and incorporate feedback into their learning

- Personal development planning (PDP) and continuous professional development (CPD): supporting and evidencing the pursuit and achievement of personal or professional competences. 
In 2007 the JISC e-learning team recognised that there was a need to more effectively draw together the lessons from all projects which had a focus on e-portfolio practice, technologies and process. Many key findings were in fact scattered throughout a range of different programs of activity. At this point, JISC took responsibility for ensuring that appropriate evaluation, synthesis, communication and planning took place across this domain. Working with appointed expert consultants, the process of synthesising what had been learnt so far from project outputs and reports was initiated (focusing on projects funded from 2007 onwards), alongside a campaign of ensuring these lessons were shared and capacity built across the UK higher and further education communities. The approach taken and the outcomes emerging from the analysis and its implications for institutional practice are discussed further below.

\section{Methodology}

This section of the paper begins with an overview of the JISC evaluation, synthesis and communication strategy for its e-portfolio work and then focuses on the methodology employed in developing an understanding of issues related to effective practice and implementation. The section also explores some of the difficulties in obtaining this understanding and resources that can support dissemination.

\section{The JISC evaluation, synthesis and communication strategy}

The multimodal approach to dissemination of lessons learnt from JISC e-portfolio developments can be seen from Table 1. This involves project reports, websites (project and JISC), landmark resources (print and online) and dissemination events (workshops, seminars, conferences). All funded JISC projects are expected to contribute to dissemination, but their primary focus is naturally on completing their own internal developments within their institution or consortium. What projects tend to focus on are their own immediate management, technical and pedagogic issues in order to achieve the project internal aims, and reporting commonly centres on issues related to achieving these and how they have overcome difficulties.

There was a clear need for JISC to support projects to be more externally focused and collect evidence of a range of practice that could support the implementation of eportfolios across the higher and further education sector. It was one of the roles of the e-portfolio expert consultants appointed from 2007 to 2009 to develop an understanding of effective practice from JISC funded projects as well as to advise JISC about strategic directions and support dissemination of program outcomes. In the first year, the expert consultancy for e-portfolios was carried out by two of the authors at the University of Nottingham, while Joyes continued this work alone in the second year. These consultants had extensive experience in using and evaluating e-portfolios in Australia and the UK, had recently completed the Becta-funded research into the impact of e-portfolios on learning (Hartnell-Young et. al., 2007) and were part of The Inter/National Coalition for Electronic Portfolio Research [http://ncepr.org/]. Their research background informed the methods of gaining an overview of project developments and providing a theoretical framework that could begin to explain why e-portfolio implementation is often problematic. 
Table 1: JISC evaluation, synthesis and communication strategy for e-portfolio implementation 2007-2009

\begin{tabular}{|c|c|c|}
\hline Mode & Description and location & Issues \\
\hline $\begin{array}{l}\text { Project } \\
\text { interim and } \\
\text { final reports } \\
\text { to JISC }\end{array}$ & $\begin{array}{l}\text { All projects complete regular interim reports } \\
\text { (some of which are made available publicly) } \\
\text { and final public reports. A template is used } \\
\text { that distinguishes between outputs and } \\
\text { outcomes including lessons learnt. }\end{array}$ & $\begin{array}{l}\text { Projects tend to focus on lessons } \\
\text { learnt relating to project } \\
\text { management rather than } \\
\text { implementation and practice and } \\
\text { tend not to include examples of use, } \\
\text { user perspectives, etc, that would be } \\
\text { useful for dissemination. }\end{array}$ \\
\hline $\begin{array}{l}\text { Project } \\
\text { websites }\end{array}$ & $\begin{array}{l}\text { All projects are expected to set up a website } \\
\text { within one month of starting and maintain } \\
\text { this for } 3 \text { years beyond the project end. }\end{array}$ & $\begin{array}{l}\text { The value of these vary widely from } \\
\text { websites that are essentially project } \\
\text { facing to those that provide a wide } \\
\text { range of resources including user } \\
\text { perspectives, case studies, podcasts } \\
\text { and videos. }\end{array}$ \\
\hline $\begin{array}{l}\text { JISC e- } \\
\text { portfolio } \\
\text { overview } \\
\text { website }\end{array}$ & $\begin{array}{l}\text { This provides an overview of JISC e-portfolio } \\
\text { activity and links to key dissemination } \\
\text { publications (see below). There is a link to a } \\
\text { summary page covering the funded JISC } \\
\text { projects with links to summary information } \\
\text { pages for each funded project. Links to } \\
\text { websites can be found at } \\
\text { http: / / www.jisc.org.uk/eportfolio }\end{array}$ & $\begin{array}{l}\text { The summary information presented } \\
\text { for each project outlines initial aims } \\
\text { and not the outputs and outcomes } \\
\text { which appear in the reports. Many } \\
\text { project websites are presented as a } \\
\text { project history though some are } \\
\text { designed to support dissemination } \\
\text { of outputs and outcomes. }\end{array}$ \\
\hline $\begin{array}{l}\text { Effective } \\
\text { practice } \\
\text { resources }\end{array}$ & $\begin{array}{l}\text { JISC has produced two landmark resources. } \\
\text { 1. Effective Practice with e-Portfolios (JISC } \\
\text { 2008b) The publication (available in print or } \\
\text { downloadable online) investigates the } \\
\text { concept of 'e-portfolio based learning' from } \\
\text { different perspectives - those of the learner, } \\
\text { the practitioner, the institution, a professional } \\
\text { body and a potential audience, summarising } \\
\text { key points of guidance in each case. It draws } \\
\text { out key points from innovative practice in } \\
\text { further and higher education and from a } \\
\text { selection of JISC-funded projects. } \\
\text { 2. The e-Portfolios infoKit (JISC infoNet, 2008) } \\
\text { is an in depth, online resource which covers } \\
\text { the main drivers, purposes, processes, } \\
\text { perspectives and issues around e-portfolio } \\
\text { use and gives a valuable synopsis of JISC- } \\
\text { funded projects on e-portfolios. }\end{array}$ & $\begin{array}{l}\text { These resources are comprehensive } \\
\text { and simply worded since those new } \\
\text { to e-portfolios may find the area } \\
\text { complex and overwhelming. } \\
\text { The advantage of the online infoKit } \\
\text { is that it links to a wide range of } \\
\text { online resources that have arisen } \\
\text { from JISC funded projects in this } \\
\text { area. } \\
\text { The infoKit also makes regular } \\
\text { updating and links to 'new' projects } \\
\text { and 'new' findings possible (an } \\
\text { update is planned in } 2009 \text { to } \\
\text { encompass the learning from } \\
\text { projects which have completed since } \\
\text { the launch in September 2008). }\end{array}$ \\
\hline $\begin{array}{l}\text { Workshops / } \\
\text { seminars / } \\
\text { conferences }\end{array}$ & $\begin{array}{l}\text { A series of } 5 \text { one day workshops were } \\
\text { delivered across the UK in 2009, with shorter } \\
\text { workshops at a number of e-learning events, } \\
\text { including the National Institute of Adult } \\
\text { Continuing Education (NIACE), Telling } \\
\text { Stories 2009, and EIfEL } 2009 \text { conferences). } \\
\text { JISC also holds annual face to face and online } \\
\text { conferences, and project only } \\
\text { conferences/ workshops. }\end{array}$ & $\begin{array}{l}\text { These workshops/seminars are } \\
\text { interactive and well received and } \\
\text { those new to e-portfolios attend } \\
\text { them, but many of the public } \\
\text { conferences can tend to 'preach to } \\
\text { the converted.' }\end{array}$ \\
\hline $\begin{array}{l}\text { E-portfolio } \\
\text { expert } \\
\text { consultant }\end{array}$ & $\begin{array}{l}\text { JISC has funded an e-portfolio expert } \\
\text { consultant project. Two academics at the } \\
\text { University of Nottingham, UK were } \\
\text { appointed 2007-9. } \\
\text { This role is discussed below. }\end{array}$ & $\begin{array}{l}\text { Gathering reliable evidence from } \\
\text { projects about developments to } \\
\text { inform dissemination can be } \\
\text { problematic. This is discussed below. }\end{array}$ \\
\hline
\end{tabular}




\section{Developing an understanding of lessons learnt}

Initial contact with newly funded projects in 2007 by the JISC program manager raised two major issues related to the wider dissemination of lessons learnt. The first was that projects needed a common language to use when discussing e-portfolios, as many projects were covering e-portfolio processes but were not identifying themselves as eportfolio projects. The second was that projects did not seem to understand the need to capture developing practice and the importance of user perspectives to share with others: evaluation was often seen as making a judgement about the achievement of project aims and objectives. The need for a common language to focus on e-portfolio practice rather than merely on e-portfolios as tools, and to support projects in recognising where they might be able to provide examples and case studies of practice, led to the development of the e-portfolio purpose-process matrix shown in Figure 1.

This matrix built on work by Hartnell-Young et. al. (2007) that usefully differentiated between e-portfolio purposes and processes. The matrix recognises that 'e-portfolios are currently used for many purposes, including formative and summative assessment, application for employment, professional accreditation, transition between institutions and/or employment, and for less high-stakes purposes such as purely recording personal growth and learning' (Joyes \& Hartnell-Young, in press). It also recognises that software tools support a range of processes, such as information capture and retrieval, planning, reflection, feedback, collaboration and presentation that are involved within these e-portfolio purposes or contexts.

\begin{tabular}{|c|c|c|c|c|c|c|c|}
\hline \multirow[b]{2}{*}{ Purpose/ context } & \multicolumn{7}{|c|}{ E-portfolio process } \\
\hline & $\begin{array}{l}\text { Inform- } \\
\text { ation } \\
\text { capture }\end{array}$ & $\begin{array}{l}\text { Inform- } \\
\text { ation } \\
\text { retrieval }\end{array}$ & $\begin{array}{c}\text { Plan- } \\
\text { ning }\end{array}$ & $\begin{array}{l}\text { Feed- } \\
\text { back }\end{array}$ & $\begin{array}{l}\text { Collab- } \\
\text { oration }\end{array}$ & $\begin{array}{c}\text { Presen- } \\
\text { tation }\end{array}$ & $\begin{array}{c}\text { Technical } \\
\text { require- } \\
\text { ments }\end{array}$ \\
\hline $\begin{array}{l}\text { Personal devt planning/ } \\
\text { continuing professional } \\
\text { development }\end{array}$ & & & & & & & \\
\hline Transition/ application & & & & & & & \\
\hline $\begin{array}{l}\text { Work based learning/ } \\
\text { employment }\end{array}$ & & & & & & & \\
\hline Assessment & & & & & & & \\
\hline Lifelong learning & & & & & & & \\
\hline Technical progress & & & & & & & \\
\hline
\end{tabular}

Figure 1: The e-portfolio purpose-process matrix (Joyes \& Hartnell-Young, in press)

The matrix became a key tool to map the e-portfolio purposes and processes with which users were engaged within projects, as well as highlighting those areas where case studies and other evidence of benefits could support the outcomes recorded in their final reports or on their websites. Projects were sent the matrix by email at the interim reporting stage and expected to complete this prior to a telephone interview with one of the e-portfolio consultants whose role was to clarify the responses. This approach served to emphasise the importance for projects of gathering evidence of practice and practitioner experiences and was instrumental in changing perceptions of the nature of evaluation evidence that JISC required for dissemination purposes. Specific guidance to projects was also provided for a project outcomes section of the final report. This guidance required e-portfolio projects to provide an updated version of the matrix and at least one case study of practice in a particular context which covered processes they had identified within the matrix. As such, the matrix was used 
as a formative tool to clarify JISC's requirements for projects in relation to developing their understanding of the evidence they could capture of tangible benefits, user experiences and issues.

Interim and final reports for twenty one projects were analysed using the JISCdetermined categories of innovations in process and practice, sustainable institutional change, tangible benefits, technical developments, lessons learned/increased knowledge, unanticipated outcomes and relevance to/response from sector. The analysis used the qualitative data analysis software Nvivo and the results are discussed further below.

\section{Results}

Analysis of the results revealed that there are tangible benefits associated with eportfolio use. These may include efficiency (such as time savings for students, academics, and administrators), enhancement (such as improving quality of evidence and feedback, skill development, satisfaction and increases in recruitment and retention) and transformation (such as innovation and changes to institutional policy). Space does not permit detailed presentation of this evidence, but the following extracts from the final report of the Flourish project that introduced e-portfolios in a number of professional development settings at the University of Cumbria serves to illuminate the nature of the evidence. Efficiency gains due to the introduction of an e-portfolio system for assessment on the new lecturer training course were reported.

I have saved stacks of time... I have had to send nothing in the post to the external examiner and have had nothing to physically photocopy. We have saved on postage and copying costs and not to mention the hours of work that is normally needed to prepare samples, marksheets etc. (Course administrator, Flourish project final report)

This of course has to be considered against the 'costs' of introducing and supporting the e-portfolio system. The same project found enhancement benefits in relation to professional development linked to staff appraisal.

The process provided an excellent opportunity for genuine reflective practice. I was surprised by the range of evidence which I could identify and to which I could link electronically, in order to demonstrate my commitment...this is a different kind of approach to that which is normally required for promotion or appointment, and I found myself exploring connections between my different roles, both past and present, which was a very positive and developmental experience. (Member of staff, Flourish project final report)

This project reveals the value of alignment of e-portfolio project developments with university staff development and teaching and learning policy, as well as professional accreditation processes within professional development contexts. As a result it provided evidence of transformation through institutional use within professional development of staff. Not only were some staff requesting to use an e-portfolio for staff appraisal in faculties where it was not being used, but staff were requesting to use the e-portfolio with their students because they had experienced the benefits for learning from their own use in the new lecturer training course. This project also provides examples of e-portfolios, video case studies of benefits to users etc. on their website at: https:/ / portfolio.pebblepad.co.uk/ cumbria/ viewasset.aspx?oid=12116\&type=webfoli o\&pageoid $=12117$ 
What was revealed by the analysis in relation to lessons learned/increased knowledge is of greatest interest to this discussion about dissemination, as it provides insights into aspects of e-portfolio use that affect whether a particular implementation provides the reported benefits. These aspects appeared as recommendations arising from preconceptions that projects initially held. They centre on the role of purpose, learning activities, processes and ownership in implementing effective e-portfolio practice and the disruptive nature of e-portfolios, and these are discussed below.

\section{The role of purpose}

For successful implementation, the purpose/s behind the use of the e-portfolios must be aligned to the particular context. Some contexts suit some purposes more than others and this needs to be determined by an analysis of the benefits (and costs) of the purpose in that particular context. This is associated with the preconceptions that:

- There is one definition of an e-portfolio. (There might be but this would need to reflect that it can be viewed as a system, a product, a set of processes suited to a range of purposes, so one definition maybe problematic);

- One e-portfolio system works in all situations. (This of course depends on the system chosen, the range of contexts in which the e-portfolio is to be used as well the intended purposes);

- After students are inducted to e-portfolio processes, for example those involved in PDP, they will apply this across their courses. (This is unlikely as the PDP purpose will be unlike other examples of e-portfolio use such as e-portfolios for transition, assessment etc.).

\section{The role of learning activity design}

There must be a conscious design and support of a learning activity/activities suited to the purpose and the context, since there are often preconceptions that:

- Users will work out how to use an e-portfolio system to suit their needs. (They will unfortunately not see the benefits without some structured activity as they are unlikely to understand the purpose);

- The e-portfolio implementation can be left to study skills specialists. (If the eportfolio is to be embedded within the curriculum, then curriculum experts need to be involved in designing learning activities and supporting them).

\section{The role of processes}

The processes involved in the creation of the e-portfolio in the particular context must be understood and both technical and pedagogic support needs to be provided. This is associated with the preconceptions that:

- Students are digital natives and so will easily adapt to using e-portfolios, for example using blogs for sharing reflections will be unproblematic;

- Users understand processes like feedback, reflective writing, selecting information, planning;

- Tutors/ mentors know how to support their students in using e-portfolios. (It is not only students who have difficulty with processes such as reflection, feedback and online collaboration.) 


\section{The role of ownership}

The e-portfolio processes and outcomes need to be owned by the student. This view leads to considering portability, choice of tool (use of their own phone, camera, audio recorder, Web 2.0 application, for example.) since there are frequently preconceptions that:

- There needs to be one e-portfolio for life. (Learners want to have control over their e-portfolio and expect portability of data; institutionally 'owned' systems can be treated with suspicion);

- Bespoke technologies, i.e. PDAs and digital cameras are best for information capture in the workplace. (The evidence is that students will more readily use their own technologies, e.g. the camera and audio recorder on their own mobile phones).

\section{The disruptive nature of e-portfolios}

E-portfolios are potentially transformative and as a result are disruptive from a pedagogic, technological and an institutional perspective because they tend not to fit exactly within existing systems. This has implications at an institutional level as they impact on the nature of the curriculum and its assessment as well as staff workload and pedagogic and technical support, particularly in novel, work based learning and life-wide contexts. This is associated with the preconceptions that:

- An e-portfolio will save everyone time;

- An e-portfolio can simply replace a paper based portfolio system;

- Human resources departments/employers will value an e-portfolio in the application process;

- University admissions welcome e-portfolios;

- A successful project implementation will readily transfer to established practice cross an institution;

- The curriculum and pedagogic approaches remain unaffected by the introduction of e-portfolios;

- Information capture in the workplace is unproblematic. (There are sensitivities in some contexts such as classrooms and hospitals);

- Access by learners to e-portfolios is unproblematic. (This may not be the case in work based learning settings).

\section{Discussion}

For those working within the projects the preconceptions they held were real and were lessons hard learned and were reported as such. However, for more experienced practitioners they may seem quite naive. It does appear that e-portfolio implementation is particularly complex and that the five aspects outlined above may well be helpfully conceived as threshold concepts.

\section{Threshold concepts}

The idea of threshold concepts emerged from a UK national research project into the possible characteristics of strong teaching and learning environments in the disciplines for undergraduate education... in the field of economics, it became clear to Erik Meyer and Ray Land, that certain concepts were held by economists to be central to the mastery of their subject. These concepts, Meyer and Land argued, could be described as 'threshold' ones because they have certain features in common. (Cousin, 2006). 
One feature is that threshold concepts are often 'troublesome' to the learner, i.e., that they may seem alien, incoherent or counter-intuitive (Perkins, 2006). Threshold concepts exist in all bodies of knowledge. It does appear that the implementation of eportfolios is particularly troublesome. We have found that in the e-portfolio area understanding emerges from technological, pedagogical, institutional, lifelong and lifewide learning perspectives. Because of this, the field engages a range of different stakeholders who need to understand the e-portfolio domain and these have different cognate backgrounds and professional interests. This is evidenced by the following findings in JISC reports and in the literature:

- It is difficult to agree on a definition for an e-portfolio. For some it is a system, for others part of a learning process, for others a presentation, and for others an archive of assets. For some it might be all of these things;

- Many educators who are actually involved with e-portfolio processes tend not to use the term at all;

- Purposes seem almost endless and so choosing where and when to implement them in the learning process can seem confusing;

- Not all e-portfolio systems/tools seem to fit well to all purposes;

- Even with guidelines and case studies of exemplars, those implementing eportfolios seem often to reinvent the wheel, making really 'obvious' mistakes compared to those who have a deeper understanding of the area;

- Understanding of e-portfolios seems to develop with experience and over time suggesting that there are key issues to understand.

Meyer and Land (2003) liken the acquisition of threshold concepts to a journey "akin to passing through a portal" or "conceptual gateway" that opens up "previously inaccessible way[s] of thinking about something". This relates to two other key features of threshold concepts. They must be transformative, i.e., a threshold concept changes the way in which the 'learner views the area, and must involve a traverse through a liminal space, i.e., "there is no simple passage in learning from 'easy' to 'difficult'; mastery of a threshold concept often involves messy journeys back, forth and across conceptual terrain." (Cousin, 2006).

There does seem to be a paradigm shift in understanding when e-portfolio knowledge is aggregated. For example, once a stakeholder understands that an e-portfolio is disruptive, because it tends not to fit exactly within existing systems, then assumptions about implementation and use become obvious. There is evidence of shifts in this understanding depending upon the perspective of those involved in the implementation, for example, only anticipating the need for scaffolding for students and not staff or only anticipating the need for technical support and not pedagogic support. Seeing the benefits of an e-portfolio will not reveal the implications for implementation though of course this set of knowledge is important too so that use can match the chosen context. The benefits themselves are not a threshold concept but they relate to one: that to do with e-portfolio purposes, i.e., the alignment of purpose to context will reveal benefits, misalignment will not.

\section{Threshold concepts and the JISC dissemination/ communication strategy}

The threshold concepts approach recognises that developing understanding is a developmental journey, both intellectually and experientially, but that once the threshold is achieved the perspective of an area is changed forever. Thus guidelines/ guidance will only make sense to a stakeholder if the threshold concept is understood 
and the preconceptions resolved. Is this why the wheel has been invented so many times in the e-portfolio area? There is evidence that e-portfolio implementation can be like a game of snakes and ladders where initial rapid progress can suffer major setbacks due to a poor understanding of the nature of e-portfolios, i.e., lack of understanding of the threshold concepts.

Therefore a key task for JISC is to begin to articulate the threshold concepts around eportfolios and their associated preconceptions and integrate these into their dissemination activities. The current strategy, shown in Table 1, employs a range of approaches that involve both transmission of knowledge, i.e., the publications and websites, as well as more constructivist approaches, such as interactive workshops where key issues related to defining e-portfolios and implementing them are thought through. The threshold concept approach would represent a strengthening of this latter approach by providing a framework of key concepts from which implications for local implementation can be thought through. However the approach brings with it a key challenge in relation to encouraging the adoption of e-portfolios. This relates to the fact that the threshold concepts approach:

- Reveals the complexity of the area rather than presenting more simplistic guidance;

- Recognises that for transformation in relation to practice to occur an institutional approach needs to be adopted that takes into account the needs of the 'learners' in a wide range of contexts.

This approach has the potential to put off would be adopters. What may be needed is a form of maturity model for e-portfolio adoption. For example, the first three threshold concepts, the role of purposes, learning activity design and processes could be usefully considered by an academic or group of academics considering implementation in one course. This would represent a very localised adoption of effective practice. The fourth threshold concept, that of the role of ownership, has potentially wider implications in that this can relate to the learners only wanting to invest time in something that they 'own' and can take forward for their own use in other contexts. Solutions to this portability issue need addressing at an institutional level and in fact this raises the fifth threshold concept: that of the disruptive nature of e-portfolios. There are often tensions between the need for contextualised and localised adoption of e-portfolios and institutional solutions. This tension can be characterised by 'let a thousand flowers bloom' compared to 'a one size fits all' approach. A mature institutional adoption would need to consider all five threshold concepts and arrive at a solution that was sensitive to the needs of all stakeholders, i.e., the learners, academics, administrators etc. in the wide range of contexts that were needed that could be supported by their information services teams.

\section{Conclusions}

This paper has outlined two key aspects in relation to influencing e-portfolio practice arising from the extensive experience of JISC-funded work in the UK in this area.

The first relates to ways of supporting projects to provide evidence of tangible benefits that can be useful for dissemination purposes. This revealed the need for a common language to focus on e-portfolio practice rather than tools, and the need to support projects in recognising where they might be able to provide examples/ case studies of practice. The e-portfolio purpose-process matrix shown in Figure 1 was an important tool in this process. 
The second key aspect relates to the fact that tangible benefits of e-portfolios won't be realised unless implementation is effectively managed and that this is a complex process. An analysis of JISC project reports in relation to lessons learned indicates that projects held a range of preconceptions and that implementation may be supported by considering a threshold concepts approach that might reveal these at the planning stage.

It has been suggested that institutions seem to move from a localised model of implementation, where only three of the threshold concepts, that of the role of purpose, learning activity design and process may be considered, to a mature institutional approach where the role of ownership and the disruptive nature of eportfolio implementation are fully considered by a wide range of stakeholders. How institutions move from the localised model to a mature institutional one is of considerable research interest. The example of the Flourish project within this paper provides an interesting case of a project engaging staff in using e-portfolios to support their own professional development. Institutional buy in to use e-portfolios for this purpose may provide a powerful means of transforming and sustaining effective practice in that it provides staff with an understanding of benefits (or not) in a particular context. These staff members are in a position to recognise benefits for the students on their courses and design appropriate learning activities, and as e-portfolio users themselves, they should be more aware of the nature of the technical and pedagogic support needed. It is clear that the longer term effects of this approach on eportfolio implementation are worthy of further exploration.

\section{References}

Beetham, H. (2005). e-Portfolios in post-16 learning in the UK: Developments, issues and opportunities. http:/ / www.jisc.ac.uk/uploaded_documents/eportfolio_ped.doc

Cousin, G. (2006). An introduction to threshold concepts. Planet, No 17, December 2006. http: / / www.gees.ac.uk/planet/p17/gc.pdf [viewed 20 June 2009].

Hartnell-Young, E., Harrison, C., Crook, C., Joyes, G., Davies, L., Fisher, T., Pemberton, R. \& Smallwood, A. (2007). The impact of e-portfolios on learning. Coventry: British Educational Communications and Technology Agency (Becta). [viewed 20 June 2009] http: / / partners.becta.org.uk/index.php?section=rh\&catcode=_re_rp_02\&rid=14007

Joyes. G., \& Hartnell-Young, E. (in press). Mapping UK e-portfolio developments within a European context. In P. Jones \& J. Luez. (Eds). E-portfolios and global diffusion: Solutions for collaborative education. Idea Group Publishing.

JISC (2006) e-Portfolios: What institutions really need to know. http: / www.jisc.ac.uk/ publications / documents/pub_lifelonglearningbps/pub_eportfoliosbp.aspx

JISC (2007). e-Portfolios: An overview. http:/ / www.jisc.ac.uk/ whatwedo/themes/elearning/eportfolios.aspx

JISC infoNet (2008). e-Portfolios infoKit http: / / www.jiscinfonet.ac.uk/infokits / e-portfolios

JISC (2008a). Stories from the regional pilot projects.

http://www.jisc.ac.uk/ whatwedo/ programmes/edistributed/regionalstories.aspx

JISC (2008b). Effective practice with e-portfolios: Supporting 21st century learning. http: / / www.jisc.ac.uk/media/ documents/publications/effectivepracticeeportfolios.pdf 
JISC (2009a). JISC e-Learning Programme.

http:/ / www.jisc.ac.uk/whatwedo/themes/elearning/programmeelearning.aspx

JISC (2009b). MLE's for Lifelong Learning: Building MLE's across HE and FE. http: / / www.jisc.ac.uk/ whatwedo/programmes/buildmlehefe.aspx

JISC (2009c). Legal and Records Management Study. [viewed Aug 2009] http:/ / www.jisc.ac.uk/ whatwedo/programmes/buildmlehefe/learnerrecordslegalstudy.aspx

JISC (2009d). Distributed e-Learning Programme. [viewed Aug 2009] http://www.jisc.ac.uk/programme_edistributed.html

JISC (2009e). HE in FE projects. [viewed Aug 2009] http:/ / www.jisc.ac.uk/whatwedo/programmes/elearningcapital/heinfe.aspx

JISC (2009f). Cross-Institutional Use of e-Learning to Support Lifelong Learners (Phase 1). [viewed Aug 2009] http: / / www.jisc.ac.uk/ whatwedo/programmes/elearningcapital/ xinstit1.aspx

JISC (2009g). Cross-Institutional Use of e-Learning to Support Lifelong Learners (Phase 2). [viewed Aug 2009] http://www.jisc.ac.uk/whatwedo/programmes/elearningcapital/xinstit2.aspx

JISC (2009h). Flourish. [viewed Aug 2009] http:/ / www.jisc.ac.uk/whatwedo/programmes / usersandinnovation/flourish.aspx

JISC (2009i). Use of technology to support admissions to higher education. [viewed Aug 2009] http:// www.jisc.ac.uk/whatwedo/programmes/elearningcapital/admissions.aspx

JISC (2009j). e-portfolio interoperability projects. [viewed Aug 2009]

http:// www.jisc.ac.uk/ whatwedo/programmes/elearningcapital/piop.aspx

JISC (2009k) e-portfolios: An overview. http:/ / www.jisc.ac.uk/ eportfolio

Meyer, J. \& Land, R. (2003). Threshold concepts and troublesome knowledge: Linkages to ways of thinking and practicing. In C. Rust, (Ed.), Improving Student Learning - ten years on. Oxford: OCSLD. [viewed 20 June 2009]. http: / / www.tla.ed.ac.uk/ etl/ docs/ETLreport4.pdf

Perkins, D. (2006). Constructivism and troublesome knowledge. In J. H. F. Meyer \& R. Land (Eds.), Overcoming barriers to student understanding: Threshold concepts and troublesome knowledge. Routledge: London and New York, pp 33-47

QAA (2001). Guidelines on HE Progress Files. [viewed 20 June 2009]. http: / / www.qaa.ac.uk/academicinfrastructure/progressfiles/guidelines /

This article received an Outstanding Paper Award at ascilite Auckland 2009 Conference, gaining the additional recognition of republication in AJET, with minor revisions. The reference for the Conference version is:

Joyes, G., Gray, L. \& Hartnell-Young, E. (2009). Effective practice with e-portfolios: How can the UK experience inform practice? In Same places, different spaces. Proceedings ascilite Auckland 2009. http:/ / www.ascilite.org.au/conferences/auckland09/ procs/joyes.pdf

Authors: Gordon Joyes, School of Education, University of Nottingham, UK Email: Gordon.Joyes@nottingham.ac.uk

Lisa Gray, Joint Information Services Committee, UK

Elizabeth Hartnell-Young, Learning Sciences Research Institute, University of Nottingham, UK 